\title{
Correlation of polyphenol content and antioxidant capacity of selected teas and tisanes from Brazilian market
}

\section{Correlação do teor de polifenóis e capacidade antioxidante de chás medicinais selecionados do mercado brasileiro}

\author{
Camila Bastos Alves ${ }^{1}$, Edson Silvio Batista Rodrigues ${ }^{2}$, Douglas Vieira Thomaz ${ }^{2}$ (D), \\ Adelmo Menezes de Aguiar Filho ${ }^{3}$, Eric de Souza Gil ${ }^{2}$ (D), Renê Oliveira do Couto ${ }^{1 *}$ (C)
}

${ }^{1}$ Universidade Federal de São João del Rei (UFSJ), Campus Centro-Oeste Dona Lindu, Divinópolis/MG - Brasil

2Universidade Federal de Goiás (UFG), Faculdade de Farmácia, Goiânia/GO - Brasil

${ }^{3}$ Universidade Federal da Bahia (UFBA), Grupo de Pesquisa GAMMA, Salvador/BA - Brasil

*Corresponding Author: Renê Oliveira do Couto, Universidade Federal de São João del Rei (UFSJ), Campus Centro-Oeste Dona Lindu, Rua Sebastião Gonçalves Coelho, 400, Bairro Chanadour, CEP: 35501-296,

Divinópolis/MG - Brasil, e-mail: rocouto@ufsj.edu.br

Cite as: Alves, C. B., Rodrigues, E. S. B., Thomaz, D. V., Aguiar Filho, A. M., Gil, E. S., \& Couto, R. O. (2020). Correlation of polyphenol content and antioxidant capacity of selected teas and tisanes from Brazilian market. Brazilian Journal of Food Technology, 23, e2020036. https://doi.org/10.1590/1981-6723.03620

\begin{abstract}
In this work, it was evaluated the phenolic content, redox behavior and antioxidant capacity of several selected teas and tisanes from Brazilian market. The samples were classified as simple (single herb) or composed (blend of two or more herbs). In addition, complementary multivariate statistical approaches were used to identify the correlation and interdependence between the amount of major phytocomponents, such as phenols and flavonoids, as well as the antioxidant activity of the products. Results showed that the total polyphenol and total flavonoid concentrations are correlated to thermodynamic feasibility of reactive oxygen species reduction. The statistical modeling differentiated the results datasets in principal components, whose flavonoid content presented itself as the main parameter to segregate data between simple and composed products. On the other hand, the whole polyphenol content, in both teas and tisanes, was more relevant regarding their antioxidant capacity than the flavonoids content. Considering that the manufactures do not display the real amount of each herb in the labels of the composed products, it was not possible to confirm whether the blends of several species lead to a substantial enhancement on their antioxidant capacity. Furthermore, the redox profile and overall polyphenol content suggest that the consumption of green and black teas as well as traditional yerba mate may be worthwhile in preventing ailments associated with oxidative stress in Brazilian population. Notwithstanding, further clinical studies are required to validate this hypothesis.
\end{abstract}

Keywords: Antioxidants; Electrochemistry; Herbal teas; Multivariate analysis; Nutraceuticals; Polyphenols.

\section{Resumo}

Apresentamos o conteúdo fenólico, o comportamento redox e o potencial antioxidante de vários chás medicinais selecionados do mercado brasileiro. As amostras foram classificadas como simples (uma única erva) ou compostas 
(mistura de duas ou mais ervas). Abordagens estatísticas multivariadas complementares foram utilizadas para esclarecer as correlações e interdependências entre as características físico-químicas e antioxidantes dos produtos. No geral, as concentrações de polifenóis e flavonoides totais se correlacionaram com a viabilidade termodinâmica da redução de espécies reativas de oxigênio. A modelagem estatística diferenciou os conjuntos de dados em componentes principais, de modo que o teor de flavonoides se apresentou como o principal parâmetro para segregar dados entre produtos simples e compostos. Por sua vez, o conteúdo de polifenóis totais nos chás foi mais relevante em sua capacidade antioxidante do que o conteúdo de flavonoides. Uma vez que os fabricantes não exibem a quantidade real de cada erva nos rótulos dos chás compostos, não foi possível confirmar se as misturas de várias espécies levam a um incremento substancial em sua capacidade antioxidante. Considerando o perfil redox e o teor de polifenóis totais, o consumo racional dos chás verde e preto e da erva-mate tradicional pode contribuir na prevenção de doenças associadas ao estresse oxidativo na população brasileira. Porém, estudos clínicos são necessários para validar essa hipótese.

Palavras-chave: Antioxidantes; Eletroquímica; Chás de ervas; Análises multivariadas; Nutracêuticos; Polifenóis.

\section{Abbreviations}

AOA, antioxidant activity; ANOVA, Analysis of Variance; ANVISA, Brazilian Health Regulatory Agency; CV, cyclic voltammetry, DPPH, 2,2-diphenyl-1-picrylhydrazyl radical; DPV, differential pulse voltammetry; $E I$, electrochemical index; PBS, phosphate-buffered saline; PCA, Principal Components Analysis; RSM, Response Surface Methodology; TF, total flavonoid contents; TP, total polyphenol contents; SWV, square wave voltammetry.

\section{Introduction}

It has been shown a remarkable growth in the consumption of phytomedicines by Brazilian population throughout the last decades, which has been associated with the pursue for healthier lifestyle as well as a growing interest on alternative therapeutic approaches (Carvalho et al., 2018). Among the herbal products quoted and marketed worldwide, teas and tisanes are favored by health-conscious consumers. In a strictly technical viewpoint, "true" teas come exclusively from the leaves of the Camellia sinensis, thereby including green, black and white tea. Regarding their differentiation, literature states the distinct harvesting process and polyphenol oxidative state, thence leading to variable organoleptic profile. On the other hand, tisanes or herbal teas are infusions made from leaves, bark, roots, flowers, berries and seeds of other medicinal herbs or spices (Chandrasekara \& Shahidi, 2018), which may be made homemade or purchased in the markets as simple (a single herb) or composed (blend of two or more herbs) products. In several countries, these beverages are the base of folk medicine systems and primary care, and are considered effective and safe when used rationally (Ren et al., 2019; Teppone, 2019).

Both teas and tisanes are source of plant secondary metabolites such as polyphenols and nutrients like water-soluble vitamins and salts whose biological activities are also remarkable in the context of the homeostatic balance of organisms. Hence, the sheer applicability of their nutraceutical properties is dependent on the used medicinal herb as well as the quality of its source and processing (Li et al., 2019; Lv et al., 2017). Given that polyphenols play a key role in the mechanisms underlying teas and tisanes antioxidant and therapeutic effects, their quantification is of upmost importance. Moreover, the determination of physicochemical features of these products e.g., redox behavior, is meaningful to imply potential health benefits attributed to nutraceuticals consumption (Sandasi et al., 2018; Zhang et al., 2018).

As the herbal phenolic profile dictates the synergy leading to biological outcomes, in which the complexity might increase in tisanes possessing more than one herb (Chen et al., 2015; Jones et al., 2018), some issues remains to be clarified, namely: i) is there any correlation between the polyphenolic content and antioxidant capacity in the teas and tisanes consumed in Brazil?; ii) which phytochemicals would be useful to discriminate teas and tisanes between simple and composed products?; and iii) does a blend of several herbs 
really enhance the synergism between the phytochemicals and the antioxidant power of a tisane as compared to a "true" tea or a single herb tisane?

Herein, it was evaluated the redox behavior of selected simple and composed teas and tisanes from Brazilian market by means of spectrometric and electroanalytical methods. For simplifying data interpretation as regards the correlation between polyphenolic content, antioxidant profile and the expected health benefits, the multivariate statistical tools of Principal Component Analysis (PCA), decision tree algorithm and Response Surface Methodology (RSM) were used.

\section{Material and methods}

\subsection{Chemicals and solutions}

Rutin (98\%), tannic acid (98\%) and DPPH were purchased from Sigma-Aldrich (Sigma-Aldrich Co., Steinheim, Germany). All other chemicals (solvents, reagents and electrolytes) herein used were of analytical grade. All solutions were prepared with ultrapure water obtained for a Mili-Q system (Millipore ${ }^{\circledR}$, Bedford, MA).

\subsection{Teas and tisanes preparation}

The fourteen selected products consisted in commercial teas ( 2 simple) and tisanes ( 7 simple and 5 composed) were acquired from supermarkets in Divinópolis city, Minas Gerais State, Brazil. Sampling was made by convenience, considering the following criteria: i) most known products sold in supermarkets and internet; and ii) having enough samples of the same batch to be used in the experimental procedures. Moreover, all samples came from products which were already registered in the Brazilian Health Regulatory Agency (in Portuguese Agência Nacional de Vigilância Sanitária (ANVISA)), and all reported procedures were conducted within the shelf life that were also disclosed by the manufacturers. Furthermore, all samples were prepared immediately before analysis according to the protocol described on the label of the products (i.e., infusion of one sachet unit in $200 \mathrm{~mL}$ water for $5 \mathrm{~min}$ ). The prepared teas and tisanes were coded using "S" to indicate simple and "C" to composed product. A particular composed tisane product was coded "D" due to its remarkable commercial appeal in Brazil. All product information is listed in Table 1 and Table S1 from Supplementary Material.

\subsection{Quantification of total polyphenols and total flavonoids}

The Total Polyphenols (TP) were determined in tannic acid equivalents following the methods described elsewhere (Mole \& Waterman, 1987), while the Total Flavonoids (TF) were calculated and expressed as Rutin Equivalents (RE) according to a previous published method (Rolim et al., 2005). For TP measurements, tannic acid was dissolved with $20 \%(\mathrm{v} / \mathrm{v})$ methanol solution and used to make the analytical curves (50 to $600 \mu \mathrm{g} / \mathrm{mL}$ ). Briefly, to $1 \mathrm{~mL}$ sample or working standard solution were added $2 \mathrm{~mL}$ of an aqueous solution containing sodium lauryl sulfate $(1 \% \mathrm{~m} / \mathrm{v})$, triethanolamine $(5 \% \mathrm{v} / \mathrm{v})$ and isopropanol $(20 \%$ $\mathrm{v} / \mathrm{v})$, and $1 \mathrm{~mL}$ of a chromogenic solution of ferric chloride $\left(\mathrm{FeCl}_{3}\right)(1.62 \mathrm{~g} / \mathrm{L}$ in $0.001 \mathrm{M} \mathrm{HCl})$. Afterwards, samples were sheltered from light for $15 \mathrm{~min}$. The absorbance was than recorded at $510 \mathrm{~nm}$. Tea sample were properly diluted with $20 \%(\mathrm{v} / \mathrm{v})$ methanol solution whether necessary. This same solution was use as blank.

Concerning TF measurements, rutin was diluted in methanol:acetic acid 0.02 M (99:1) solution to make the analytical curves in the range of $2.5 \mathrm{up}$ to $40 \mu \mathrm{g} / \mathrm{mL}$. This same solvent was use as blank. The absorbance of $2 \mathrm{~mL}$ sample or working standard solution were directly measured at $361 \mathrm{~nm}$. For both TP and TS assessment, a SP220 UV/Vis spectrophotometer (Biospectro ${ }^{\circledR}$, Curitiba, PR, Brazil) was used and the 
experiments were performed in triplicate. Data were expressed as the average amount of TP $(\mathrm{mg})$ or TF $(\mu \mathrm{g})$ per unit (sachet) of tea or tisane intake as recommended by the manufacturer in the label of the products.

\subsection{Antioxidant activity assessment}

The determination of free radical scavenging capacity was conducted according to previous outreaches (Leite et al., 2018). The antioxidant activity (AOA) in terms of \% discoloration was calculated based on the original color intensity of pure DPPH solution. Henceforth, a volume of $0.3 \mathrm{~mL}$ of sample was added to a test tube containing $2.7 \mathrm{~mL}$ of DPPH at $0.066 \mathrm{mmol} / \mathrm{L}$. The tubes were then covered with plastic film and kept 15 min sheltered from light. Absorbance was monitored at $517 \mathrm{~nm}$ using UV-Vis spectrophotometer $\left(\mathrm{Jasco}^{\circledR} \mathrm{V}-530\right)$.

\subsection{Electrochemical determination of redox kinetics and thermodynamics}

In order to explore the physicochemical features of herbal preparations, all samples were subjected to voltammetric screenings, such as: Cyclic Voltammetry (CV), Square Wave Voltammetry (SWV) and Differential Pulse Voltammetry (DPV) (Thomaz et al., 2018a, 2018b). All experiments were conducted using potentiostate/galvanostate PGSTAT ${ }^{\circledR}$ model 204 coupled to FRA32M module (Metrohm) and integrated to NOVA $2.1^{\circledR}$ software. Electrochemical experiments were conducted in $1 \mathrm{~mL}$ electrochemical half-cell using tri-electrode system. The electrodes consisted of glassy carbon working electrode (1 mm diameter); $\mathrm{Ag} / \mathrm{AgCl} / \mathrm{KCl}_{\text {sat }}$ reference electrode; and a platinum wire as counter electrode. The experimental conditions to each test were: scan rate of $100 \mathrm{mV} / \mathrm{s}$ between 0 to $0.8 \mathrm{~V}$ for $\mathrm{CV}$; pulse amplitude of $50 \mathrm{mV}$, frequency of $50 \mathrm{~Hz}$ and potential increment of $2 \mathrm{mV}$ for SWV; and pulse amplitude of $50 \mathrm{mV}$, pulse width of $0.5 \mathrm{~s}$, and scan rate of $10 \mathrm{mV} / \mathrm{s}$ DPV. All experiments were conducted in $0.9 \mathrm{~mL}$ of PBS solution $(0.1 \mathrm{~mol} / \mathrm{L}), \mathrm{pH} 7.0$. For the tests, $0.1 \mathrm{~mL}$ of each sample was added to PBS solution. All experiments were conducted in triplicates, and voltammetric data was rendered and presented using Origin Pro $8^{\circledR}$ software package (Northampton, MA, EUA).

Voltammetric data was used to investigate redox kinetics and thermodynamics, which can be correlated to antioxidant capacity. Moreover, DPV data was used to calculate the Electrochemical index (EI) for each sample. The $E I$ correlates the faradaic current output representing redox kinetics to the potential energy levels represented by the electric potential. This correlation allows the calculation of a dataset which indicates thermodynamic and kinetic feasibility of reactive oxygen species reduction, thence indicating antioxidant capacity. The EI was calculated according to Equation 1.

$E I=\frac{I_{p a 1}}{E_{p a 1}}+\frac{I_{p a 2}}{E_{p a 2}}+\frac{I_{p a n}}{E_{p a n}}$

Wherein, $E I$ is the electrochemical index $(\mu \mathrm{A} / \mathrm{mV}) ; I_{\mathrm{pan}}$ is the nominal value of the faradaic current $(\mu \mathrm{A})$ associated to anodic peak $(n)$; and $E_{\mathrm{pan}}$ is electric potential $(\mathrm{mV})$ associated to the anodic peak $(n)$.

\subsection{Multivariate statistical analysis}

In order to correlate results, minimize dimensions basing on variance/correlation matrix and stablish a statistical model capable of explaining the findings, PCA was used (Leite et al., 2018). All data were considered to stablish an appropriate decision tree. Data were analyzed using Origin Pro $8^{\circledR}$ software package (Northampton, MA, USA). To simplify interpretation of the relationships between the phytochemical contents and the antioxidant properties in the samples, a correlation matrix was prepared using the Statistica 7 software package (Statsoft Inc., Tulsa, OK). 
Furthermore, the RSM was performed by using this same software package to accurately determine the effects of the phytochemical contents in the antioxidant properties of the products. Due to the great scale amplitude in the results of the independent variables (i.e., TP and TF) and to enable the RSM analysis, the data between -1 and +1 were normalized by applying the following mathematical rule displayed by Equation 2:

$$
\text { Normalized value }=\frac{(\text { realvalue }- \text { averagevalue })}{(\text { greatest value }- \text { lowest value })}
$$

The response function applied in the RSM was a quadratic polynomial equation, given by Equation 3:

$$
Y=\beta_{0}+\beta_{1} X_{1}+\beta_{2} X_{2}+\beta_{11} X_{1}^{2}+\beta_{22} X_{2}^{2}+\beta_{12} X_{1} X_{2}
$$

In Equation 3, $Y$ is the predicted response (dependent variable i.e., $\mathrm{AOA}$ or $\mathrm{EI}$ ); $\beta_{0}$ is the model constant; $X_{1}$ and $X_{2}$ are independent variables (i.e., TP and TF); $\beta_{1}$ and $\beta_{2}$ are linear coefficients; $\beta_{11}$ and $\beta_{22}$ are the quadratic coefficients; and $\beta_{12}$ is the cross-product coefficients. All analysis considered confidence interval which was set to 0.95 and statistical significance was attributed to $p<0.05$.

\section{Results and discussion}

\subsection{Analysis of total polyphenols, flavonoids and antioxidant capacity}

The results of TP and TF, free-radical reducing properties (AOA) and the thermodynamic and kinetics of reactive oxygen species reduction $(E I)$ are shown in Table 1 . The green tea $(C$. sinensis $-\mathrm{S} 1302)$ presented the greatest values for TP, AOA and EI, whereas the greatest amounts of TF were obtained for the traditional Yerba mate (Ilex paraguariensis - S701) followed by peppermint (Mentha spicata - S0301). The smallest values for TP and EI were observed for chamomile (Matricaria chamomilla - S0101), while the composed products $\mathrm{C} 0202$ and $\mathrm{C} 0802$ had the smallest amounts of TF and AOA, respectively. The obtained results corroborate with previous findings which demonstrated that chamomile tisane has lower TP, TF and AOA as compared to green tea and black tea (Shannon et al., 2018). Nonetheless, the trend herein observed in the AOA of green tea in comparison to peppermint was the opposite of the reported in other studies (Cleverdon et al., 2018).

Considering that all teas and tisanes underwent extraction using a polar protic solvent such as water, it can be suggested that polyphenols were extracted either in glycosylated and aglycone forms (Shao et al., 2018). In this context, the preparation method plays a key role on the potential health benefits of herbal beverages, due to its effects on the extraction of the antioxidant molecules from the plant material (Cleverdon et al., 2018; Damiani et al., 2019; McAlpine \& Ward, 2016). Although tea and tisane preparation in this work followed the protocol indicated by the manufacturers in order to mimic popular use, some reports demonstrated that this procedure does not often lead to effective extraction of the phytochemicals from the samples up to exhaustion (Silveira et al., 2017; Sgorbini et al., 2019).

From a phytopharmaceutical technology point of view, to achieve an optimal yield, it should be considered that every single herbal raw material may present singular morphological features (e.g., particle size, shape and porosity) and chemical profile. Thus, extraction procedures could be individualized product by product instead of standardized in a single protocol. In this pursuit, manufactures would considerer to perform a broad literature review regarding processing parameters such as drug/solvent ratio, extraction time, temperature and method. For instance, the microwave-assisted extraction is a very well-known technique that also enables the use of water as solvent and has proved to be more effective than infusion (Petkova et al., 2017), besides presenting versatility, promptness, affordability and easiness to be performed at home setting (Kala et al., 2016). 
Table 1. Results of phytochemicals contents and antioxidant capacity tests for the various teas and tisanes purchased from Brazilian market.

\begin{tabular}{|c|c|c|c|c|c|c|}
\hline Sample type & Code & Herbal composition & $\begin{array}{c}\text { TP } \\
\text { (mg/unit) }\end{array}$ & $\begin{array}{c}\text { TF } \\
\text { (mg/unit) }\end{array}$ & $\begin{array}{c}\text { AOA } \\
\text { (\% discoloration) }\end{array}$ & $\begin{array}{c}E I \\
(\mu \mathrm{A} / \mathrm{mV})\end{array}$ \\
\hline Tisane (simple) & S0101 & Matricaria chamomilla $\mathrm{L}$. & 14.00 & 380.28 & 29.96 & 2.37 \\
\hline Tisane (simple) & S0301 & Mentha spicata L. & 103.48 & 1370.89 & 45.93 & 15.57 \\
\hline Tisane (simple) & S0401 & $\begin{array}{c}\text { Cymbopogon citratus (D.C.) } \\
\text { Stapf }\end{array}$ & 16.97 & 408.45 & 32.88 & 6.54 \\
\hline Tisane (simple) & S0501 & Pimpinella anisum L. & 21.04 & 246.48 & 35.01 & 7.41 \\
\hline Tea (simple) & S0601 & $\begin{array}{l}\text { Camellia sinensis (L.) Kuntze } \\
\text { (Black tea) }\end{array}$ & 150.34 & 1258.22 & 34.35 & 21.31 \\
\hline Tisane (simple) & S0701 & $\begin{array}{l}\text { Ilex paraguariensis A. St.-Hil. } \\
\text { (traditional) }\end{array}$ & 449.18 & 1990.61 & 41.41 & 22.88 \\
\hline Tisane (simple) & S1102 & Peumus boldus Molina & 98.02 & 1248.83 & 39.68 & 16.69 \\
\hline Tisane (simple) & S1202 & $\begin{array}{l}\text { Ilex paraguariensis A. St.-Hil. } \\
\text { (roasted) }\end{array}$ & 118.16 & 835.68 & 37.28 & 18.17 \\
\hline Tea (simple) & $\mathrm{S} 1302$ & $\begin{array}{l}\text { C. sinensis (L.) Kuntze (Green } \\
\text { tea) }\end{array}$ & 514.90 & 1215.96 & 61.38 & 45.76 \\
\hline $\begin{array}{c}\text { Tisane } \\
\text { (composed) }\end{array}$ & $\mathrm{C} 0202$ & $\begin{array}{c}\text { C. sinensis (L.) Kuntze (Green } \\
\text { tea), Zingiber officinale R., M. } \\
\text { spicata L., Ananas comosus (L.) } \\
\text { Merril. }\end{array}$ & 46.43 & 220.66 & 54.32 & 11.85 \\
\hline $\begin{array}{c}\text { Tisane } \\
\text { (composed) }\end{array}$ & $\mathrm{C} 0802$ & $\begin{array}{l}\text { Hibiscus sabdariffa L., Malus } \\
\text { sylvestris (L.) Miller, Rosa canina } \\
\text { L., Citrus sinensis (L.) Osbeck, } \\
\text { Punica granatum L., Vaccinium } \\
\text { macrocarpon Ait. } \\
\end{array}$ & 49.64 & 591.55 & 18.90 & 4.48 \\
\hline $\begin{array}{c}\text { Tisane } \\
\text { (composed) }\end{array}$ & C1002 & $\begin{array}{l}\text { H. sabdariffa L., C. sinensis (L.) } \\
\text { Kuntze (Green tea), } \\
\text { Cinnamomum cassia (L.) J.Presl, } \\
\text { Capsicum sp. L., Fragaria } \\
\text { ananassa L., V. myrtillus } \\
\end{array}$ & 66.74 & 291.08 & 27.82 & 2.45 \\
\hline $\begin{array}{c}\text { Tisane } \\
\text { (composed) }\end{array}$ & C1401 & $\begin{array}{l}\text { C. sinensis (L.) Kuntze (Green } \\
\text { tea), Malus pumila } \times \text { M. sylvestris } \\
\text { (L.) Mill. (Granny Smith cultivar) }\end{array}$ & 213.76 & 807.51 & 52.06 & 31.27 \\
\hline $\begin{array}{c}\text { Tisane } \\
\text { (composed) }\end{array}$ & D0903 & $\begin{array}{c}\text { C. sinensis (L.) Kuntze (Green } \\
\text { tea), Baccharis trimera (Less.) } \\
\text { DC., I. paraguariensis A. St.-Hil., } \\
\text { Z. officinale R., Rosmarinus } \\
\text { officinalis L., Mentha spicata L., } \\
\text { Paullinia cupana Kunth., Salvia } \\
\text { officinalis L. }\end{array}$ & 126.14 & 873.24 & 51.26 & 20.36 \\
\hline
\end{tabular}

AOA, antioxidant activity in terms of DPPH radical scavenging capacity; $E I$, electrochemical index calculated from differential pulse voltammetry data; TP, total polyphenols content (tannic acid equivalent); TF, total flavonoids content (rutin equivalent); Data presented as means of triplicates.

Overall comparisons between simple and composed products were not possible to be drawn since the quantitative content of the composed herbal teas remains unclear. Even though manufacturers label the products as containing several herbs, likely seeking to indicate that they can be more attractive for medicinal purposes and bring purportedly benefits for the costumer's health. Notwithstanding, there was no juridical mechanism to address the veracity of such allegations by the time this research was conducted.

Therefore, we consider that current national legislation for this kind of product should be changed to clarify the trustfulness of labeling information to the costumers. This would be a step forward to achieve the rational use of phytotherapics and nutraceuticals in Brazil, enabling the better understanding of several issues related 
to the quality and safety of these products, e.g., chemical standardization; daily intake calculation; and prediction of drug-herb interaction and clinically relevant side effects.

\subsection{Redox behavior of the samples}

The CV was herein employed to preliminarily evaluate redox kinetics and thermodynamics. As can be seen in Figure 1, the samples presented distinct redox profiles, being detected three anodic peaks, namely 1a, 2a and 3a, which are all correlated to the oxidation of electroactive compounds (e.g. phenols). All anodic processes were gathered upon the application of potentials bellow $0.8 \mathrm{~V}$. Moreover, some products (i.e., S1102, S1302 and D0903) presented wide anodic peaks, suggesting peak overlapping. Both traditional and roasted Yerba mate simple tisanes (S0701 and S1202, respectively) presented a single cathodic process, namely $1 \mathrm{c}$, which is correlated to the reduction of electroactive species in the samples. The CV profile obtained for the black tea sample (S0601) was identical to that of commercial samples purchased in another region of the country (Thomaz et al., 2018a), thus suggesting the identity of the raw material used.

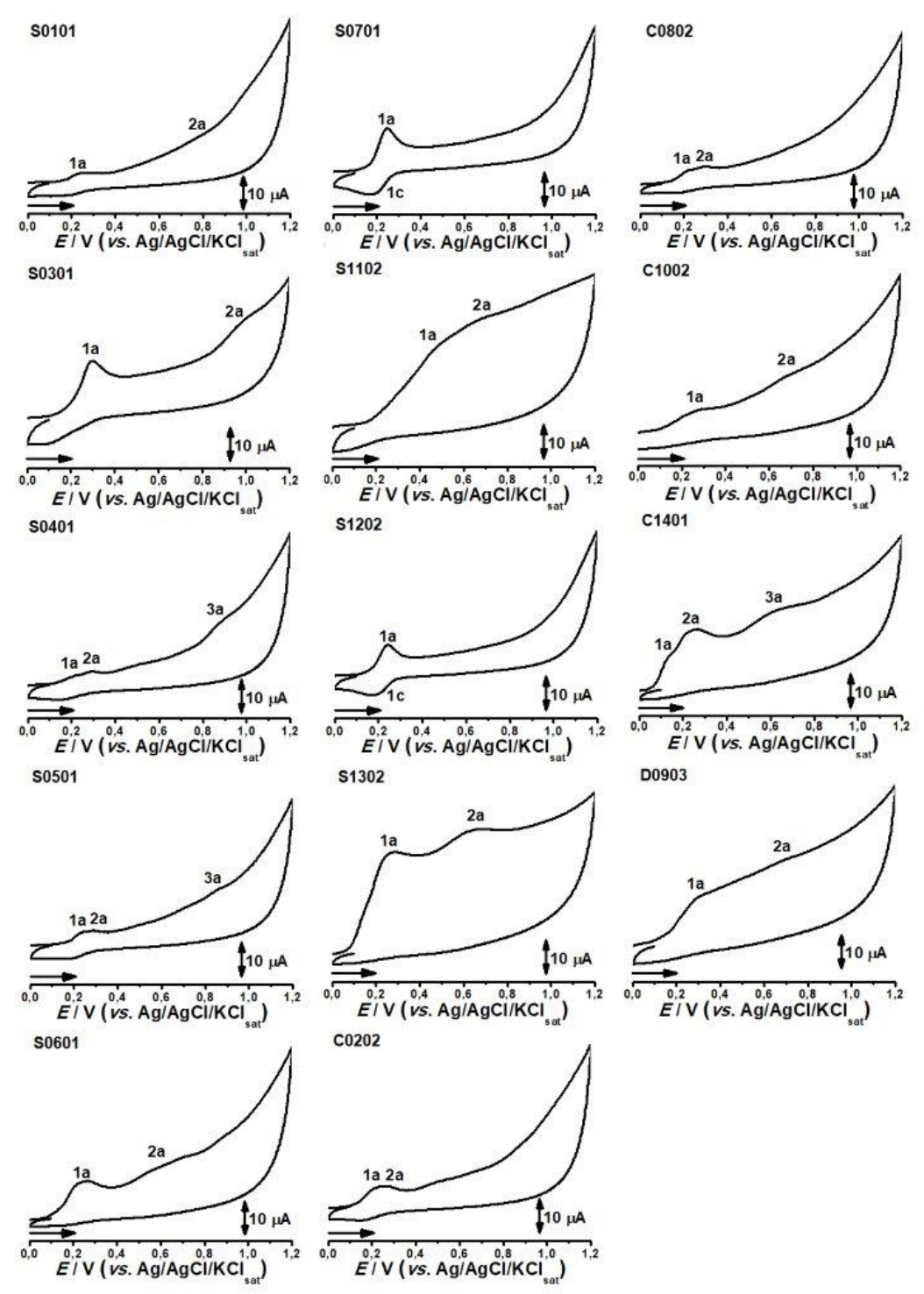

Figure 1. Cyclic voltammograms of selected tea samples from Brazilian market. Experiments were performed using $0.1 \mathrm{~mL}$ tea or tisane samples and $0.9 \mathrm{~mL}$ phosphate buffer $\left(0.1 \mathrm{~mol} \mathrm{~L}^{-1}\right), \mathrm{pH} 7.0 ; 1 \mathrm{a}, 2 \mathrm{a}$ and 3 a correspond to anodic peaks, while $1 \mathrm{c}$ correspond to a cathodic peak. 
The SWV was performed in order to further investigate redox reversibility, being the results presented in Figure 2. The SW voltammetric findings evidenced cathodic processes which were not detected by means of $\mathrm{CV}$. This effect is a result of SWV greater sensibility towards redox shifts detection. Moreover, results evidenced that in the reversible processes detected by means of $\mathrm{CV}$, reversibility can be suggested hence equivalence of kinetic parameters $\left(I_{\mathrm{pa}} / I_{\mathrm{pc}} \approx 1\right)$. These redox pairs were detected upon application of potentials bellow $0.5 \mathrm{~V}$ (Figure 2), therefore ratifying the antioxidant appeal of these products against oxidation-induced DNA damage since it has been noticed that distinct DNA purine base lesions are formed in the potential ranges of $0.5 \mathrm{~V}<\mathrm{E}<1.5 \mathrm{~V}$ and $\mathrm{E}>1.5 \mathrm{~V}$ (Reipa et al., 2018).

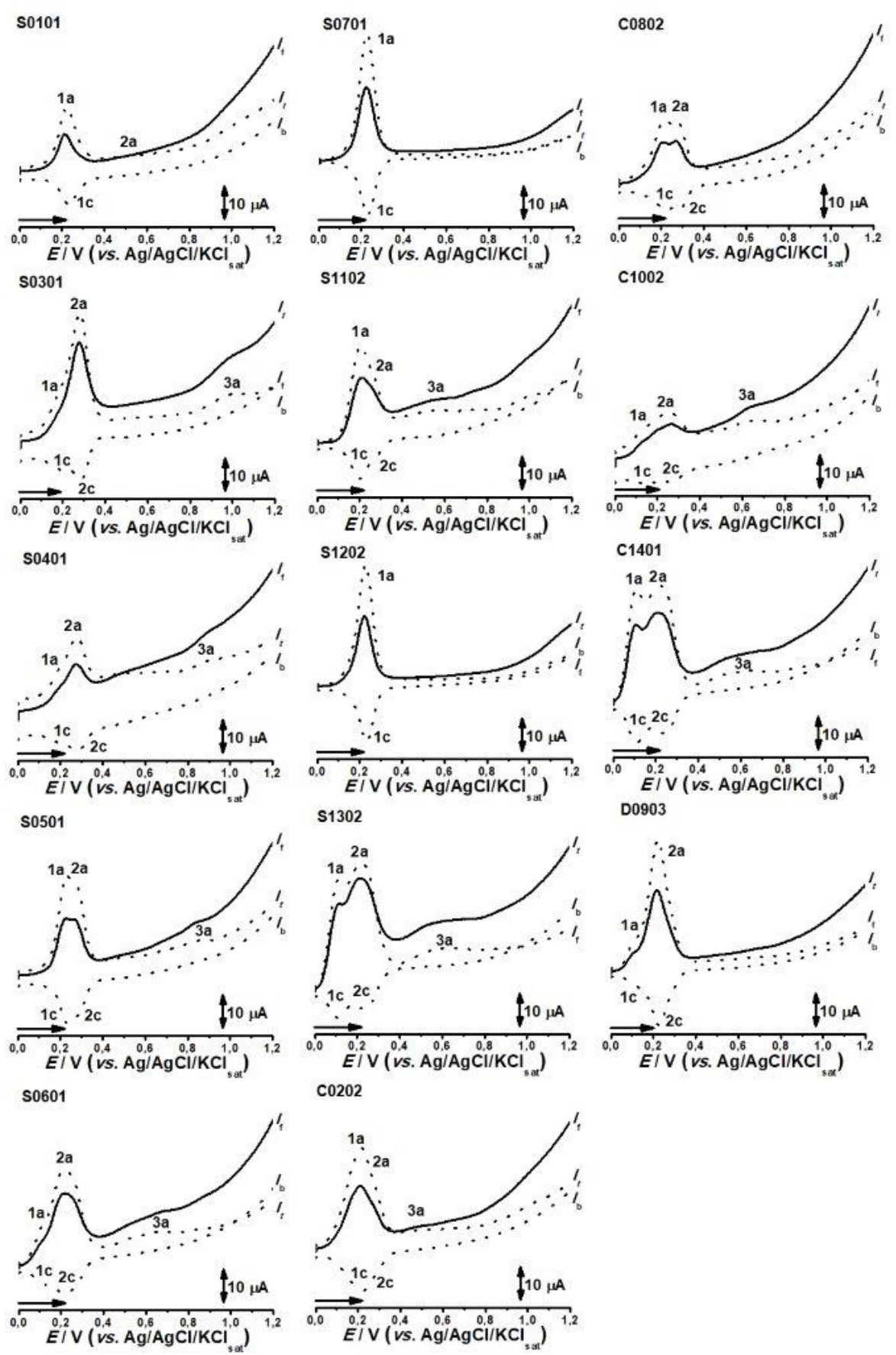

Figure 2. Squared wave voltammograms of selected tea samples from Brazilian market. Total current $\left(I_{\mathrm{t}}\right)$, anodic $\left(I_{\mathrm{f}}\right)$ and cathodic $\left(I_{\mathrm{b}}\right)$ evidenced in the figure. Experiments were performed using $0.1 \mathrm{~mL}$ tea or tisane samples and $0.9 \mathrm{~mL}$ phosphate buffer $\left(0.1 \mathrm{~mol} \mathrm{~L}^{-1}\right), \mathrm{pH} 7.0 ; 1 \mathrm{a}, 2 \mathrm{a}$ and $3 \mathrm{a}$ correspond to anodic peaks, while $1 \mathrm{c}$ and $2 \mathrm{c}$ correspond to cathodic peaks. 
Electrochemical and colorimetric assays have been considered useful techniques to evaluate the redox features of complex samples such as foodstuff and nutraceuticals (Arteaga et al., 2012; Macêdo et al., 2017; Oliveira Neto et al., 2017a, 2017b, 2017c; Leite et al., 2018; Lino et al., 2014; Oliveira-Neto et al., 2016). Therefore, both CV and SWV results revealed that the aqueous extracts presented kinetic and thermodynamic processes which correlate to antioxidant potential. Given that endogenous antioxidants undergo oxidation at potentials bellow $0.5 \mathrm{~V}$ in order to reduce reactive oxygen species, and stabilize them, the presence of faradaic signals presenting high kinetic values upon the application of small potentials endorse the presence of antioxidant compounds in both teas and tisane products.

Considering that polyphenols such as flavonoids and phenolic acids are stated to undergo oxidation to balance endogenous antioxidants (Gil \& Couto, 2013), the positive correlation between EI, AOA and total phenols and flavonoids is an expected result. Thus, simple tisanes such as S0701 (traditional yerba mate) and $\mathrm{S} 1202$ (roasted yerba mate) presented cathodic processes $E_{\mathrm{p} 1 \mathrm{c}} \approx 0.21 \mathrm{~V}$ and $E_{\mathrm{p} 2 \mathrm{c}} \approx 0.22 \mathrm{~V}$ which do correlate to their subsequent anodic processes, what is further supported by literature (Moreno et al., 2019; Thomaz et al., 2018a).

\subsection{Correlations between polyphenol content and antioxidant capacity}

The PCA results are displayed in Figure 3. The variables associated to antioxidant capacity present significative dimensional shrinkage, being the first principal component capable of explaining more than $70 \%$ of the original dataset variability. Besides, the two first principal components detain more than $90 \%$ of the model accumulated variability. The antioxidant capacity (i.e., AOA and EI) as well as TP and TF presented non-linear tendencies, thus allowing a clear segregation of the datasets into two distinct groups, namely i) simple; and ii) composed, though there was a small overlap in in the first principal component.

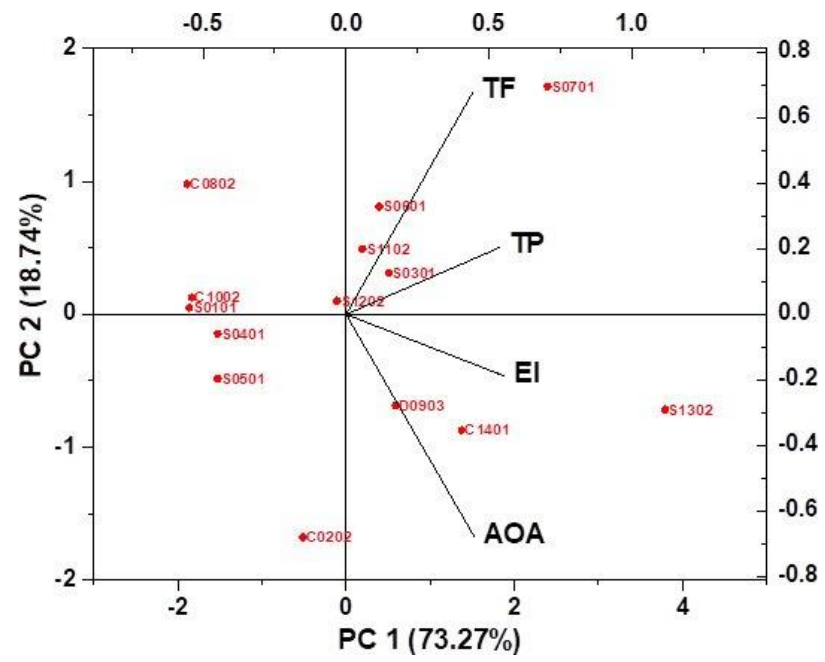

Figure 3. Principal Component Analysis of raw data for total polyphenols (TP, tannic acid equivalent), total flavonoids (TF, rutin equivalent), antioxidant activity (AOA) and electrochemical index (EI) of selected teas and tisanes from Brazilian market.

The multivariate analysis was also used to graphically demonstrate the interdependence between datasets. As can be seen in the correlation matrix displayed in Figure 4, a moderate correlation was observed between the TP and the AOA, but the free-radical reducing properties did not significantly depend on the TF. The EI strongly depended on both $\mathrm{TF}$ and $\mathrm{AOA}$, and the TP presented a very strong correlation with the real antioxidant capacity of the products as determined by the $E I$. Similar trends were found in studies on other food matrices (Oliveira Neto et al., 2017a, 2017b, 2017c; Shao et al., 2018) and phytomedicines (Leite et al., 2018; Moreno et al., 2019). 


\section{TP TF AOA EI \\ TP 1.000 .720 .560 .85 \\ TF 0.721 .000 .300 .60 AOA 0.560 .301 .000 .78 El $\quad 0.850 .600 .781 .00$}

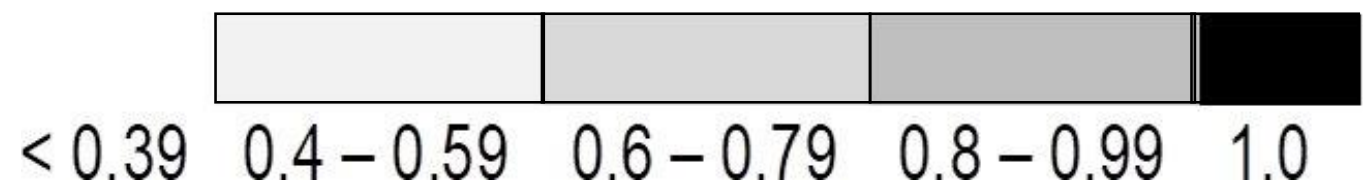

Figure 4. Correlation matrix in the evaluation of the correlations between datasets for total polyphenols (TP, tannic acid equivalent), total flavonoids (TF, rutin equivalent), antioxidant activity (AOA) and electrochemical index (EI) of selected teas and tisanes from Brazilian market.

In Figure 5, the decision tree presents the classification of all products results in either simple or composed. From this model, it was possible to assert that greater TF ( $\geq 1045 \mu \mathrm{g} / \mathrm{unit}$ ) do correlate to greater possibility of a product undergo classification as Simple. This prediction was validated by the data presented in Table 1, since only samples of teas and simple tisanes (i.e., S0309, S0601, S0701, S1102 and S1302) achieved this level of TF. For inferior values, it was necessary to take TP into consideration and then AOA results.

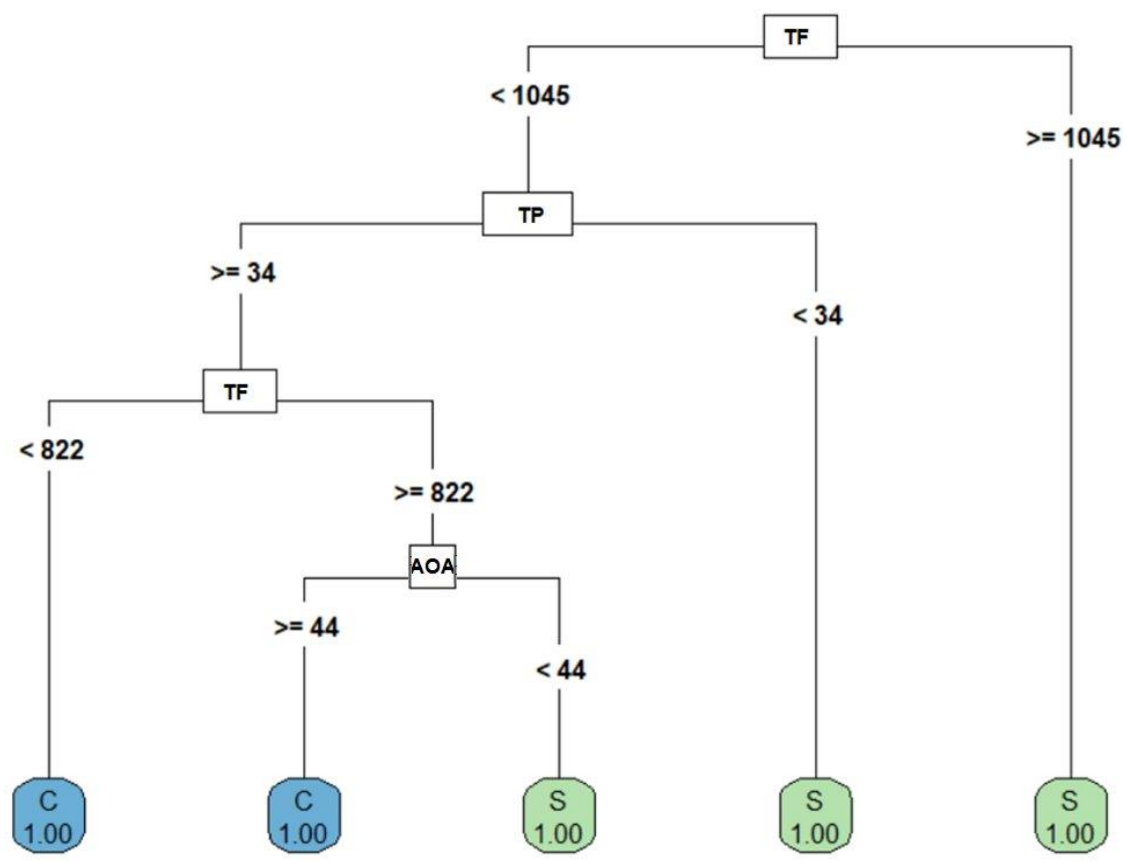

Figure 5. Decision tree in the evaluation of the correlations between datasets for total polyphenols (TP, tannic acid equivalent), total flavonoids (TF, rutin equivalent), antioxidant activity (AOA) and electrochemical index (EI) of selected teas and tisanes from Brazilian market. 
Therefore, the decision tree identified flavonoids as the main standard to which product may be differentiated upon. To the best of our knowledge, this result is remarkable and unprecedent for this type of product. More experiments with greater number of products are needed in order to further explore and therefore evidence the reason for this finding. The $E I$ did not figured as a variable in decision tree algorithm possibly hence its sheer dependence on sample electroactive compounds thermodynamics instead of flavonoids.

Concerning the RSM analysis, a summary of the main effects affecting the antioxidant properties of the products (linear, quadratic or cross product coefficient) are listed in Table S2 of Supplementary Material. Table S2 also displays comments on the types of the effects as represented by positive (directly proportional) and negative (inversely proportional) signs and about the prediction power of the fitted mathematical models represented by the determination coefficient $\left(\mathrm{R}^{2}\right)$. The response surface plots of the effects of TP and TF on the AOA and $E I$ of the evaluated products are displayed in Figures 6 and 7, respectively.

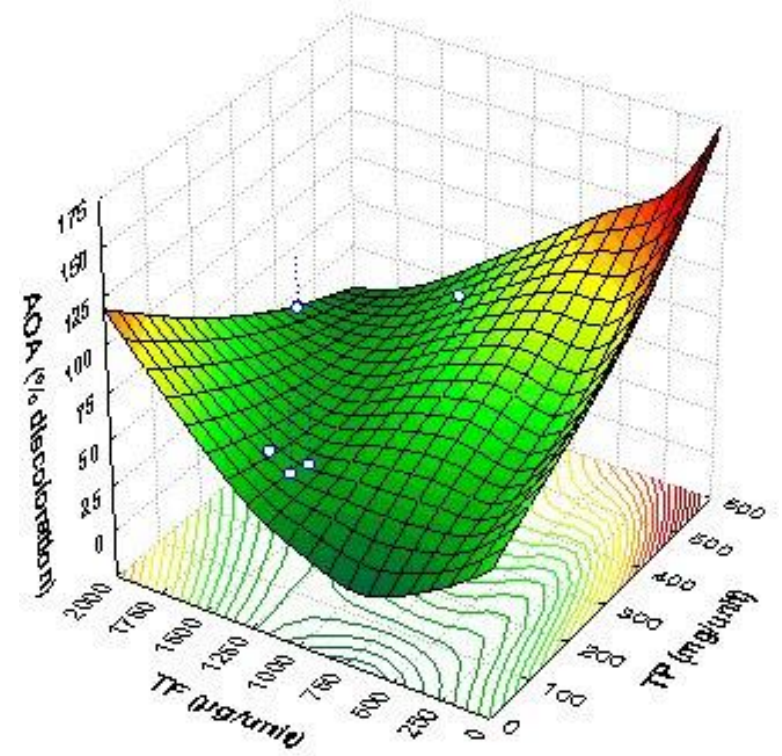

Figure 6. Response surface plot of the effects of total polyphenols (TP, tannic acid equivalent) and total flavonoids (TF, rutin equivalent) on the antioxidant activity (AOA) of selected teas and tisanes from Brazilian market.

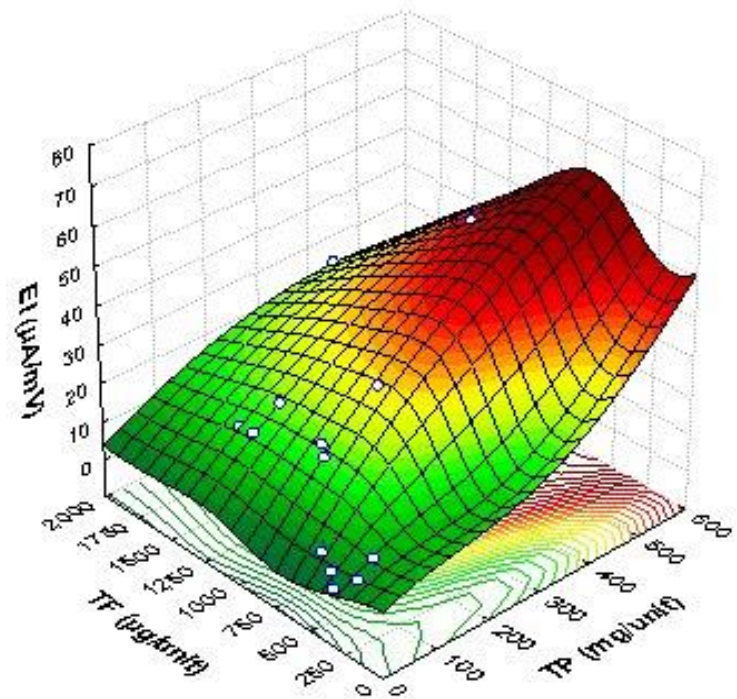

Figure 7. Response surface plots of the effects of total polyphenols (TP, tannic acid equivalent) and total flavonoids (TF, rutin equivalent) on the electrochemical index $(E I)$ of selected teas and tisanes from Brazilian market. 
Results demonstrate that the TP exerted a positive effect in both AOA and EI, i.e., an increase on TP in the product does correlate with a linear rate increase in AOA and $E I$. On the other hand, increasing the TF in the product decreased its $E I$. Therefore, although being determinant in discriminating the products, the TF is not the major factor affecting their real antioxidant properties, which depend on the synergic effect of the whole polyphenol composition in the nutraceutical. Also, the synergism between the phytochemicals in the tisanes does not depend on the number of species comprising it $\left(\mathrm{R}^{2}<0.23\right.$, data not shown).

\section{Conclusion}

The TP and TF concentrations do correlate to thermodynamic feasibility of reactive oxygen species reduction as demonstrated by free-radical scavenging tests and electrochemical assays. According to the PCA analysis, the flavonoid content was the main parameter to segregate data between simple and complex products. The restricted number of samples, and the lack of information regarding the real quantitative contribution of each single herb in the composed tisanes are the major limitations of this work. Altogether, these issues hindered us to determine whether the blend of several herbs can bring a substantial enhancement in their antioxidant properties. The intake of teas and simple tisanes with the greater total polyphenol contents such as green and black teas (C. sinensis) and Yerba mate (I. paraguariensis) may bring more benefits to the health of costumer regarding the prevention of damages related to oxidative stress when compared to the complex tisanes herein analyzed. Our findings do corroborate to the rational consumption of these herbal products as nutraceuticals and reinforce their potential as health promotion strategy at the basic level.

\section{Acknowledgements}

This study was financed in part by the Coordenação de Aperfeiçoamento de Pessoal de Nivel Superior Brazil (CAPES) - Finance Code 001. The authors greatly thank Prof. João Máximo Siqueira (UFSJ) for supplying the chemical analytical standards to the quantification of total polyphenols and flavonoids.

\section{References}

Arteaga, J. F., Ruiz-Montoya, M., Palma, A., Alonso-Garrido, G., Pintado, S., \& Rodríguez-Mellado, J. M. (2012). Comparison of the Simple Cyclic Voltammetry (CV) and DPPH assays for the determination of antioxidant capacity of active principles. Molecules (Basel, Switzerland), 17(5), 5126-5138. PMid:22555300. http://dx.doi.org/10.3390/molecules17055126

Carvalho, A. C. B., Lana, T. N., Perfeito, J. P. S., \& Silveira, D. (2018). The Brazilian market of herbal medicinal products and the impacts of the new legislation on traditional medicines. Journal of Ethnopharmacology, 212, 29-35. PMid:28987598. http://dx.doi.org/10.1016/j.jep.2017.09.040

Chandrasekara, A., \& Shahidi, F. (2018). Herbal beverages: bioactive compounds and their role in disease risk reduction - A review. Journal of Traditional and Complementary Medicine, 8(4), 451-458. PMid:30302325. http://dx.doi.org/10.1016/j.jtcme.2017.08.006

Chen, Q., Zhang, D., Pan, W., Ouyang, Q., Li, H., Urmila, K., \& Zhao, J. (2015). Recent developments of green analytical techniques in analysis of tea's quality and nutrition. Trends in Food Science \& Technology, 43(1), 63-82. http://dx.doi.org/10.1016/j.tifs.2015.01.009

Cleverdon, R., Elhalaby, Y., McAlpine, M., Gittings, W., \& Ward, W. (2018). Total polyphenol content and antioxidant capacity of tea bags: comparison of black, green, red rooibos, chamomile and peppermint over different steep times. Beverages, 4(1), 15. http://dx.doi.org/10.3390/beverages4010015

Damiani, E., Carloni, P., Rocchetti, G., Senizza, B., Tiano, L., Joubert, E., de Beer, D., \& Lucini, L. (2019). Impact of cold versus hot brewing on the phenolic profile and antioxidant capacity of rooibos (Aspalathus linearis) herbal tea. Antioxidants, 8(10), 499. PMid:31640245. http://dx.doi.org/10.3390/antiox8100499

Gil, E. S., \& Couto, R. O. (2013). Flavonoid electrochemistry: a review on the electroanalytical applications. Brazilian Journal of Pharmacognosy, 23(3), 542-558. http://dx.doi.org/10.1590/S0102-695X2013005000031

Jones, A., Acquaviva, A., Dennis, G. R., Shalliker, R. A., \& Soliven, A. (2018). Bioactive screening of complex tea samples using the ferric reducing antioxidant power assay incorporating reaction flow HPLC columns for post column derivatisations. Microchemical Journal, 138, 197-202. http://dx.doi.org/10.1016/j.microc.2018.01.005

Kala, H. K., Mehta, R., Sen, K. K., Tandey, R., \& Mandal, V. (2016). Critical analysis of research trends and issues in microwave assisted extraction of phenolics: have we really done enough. TrAC Trends in Analytical Chemistry, 85, 140-152, http://dx.doi.org/10.1016/j.trac.2016.09.007 
Leite, K. C. S., Garcia, L. F., Lobón, G. S., Thomaz, D. V., Moreno, E. K. G., Carvalho, M. F., Rocha, M. L., Santos, W. T. P., \& Gil, E. S. (2018). Antioxidant activity evaluation of dried herbal extracts: an electroanalytical approach. Brazilian Journal of Pharmacognosy, 28(3), 325-332. http://dx.doi.org/10.1016/j.bjp.2018.04.004

Li, Y., Yang, P., Luo, Y., Gao, B., Sun, J., Lu, W., Liu, J., Chen, P., Zhang, Y., \& Yu, L. (2019). Chemical compositions of chrysanthemum teas and their anti-inflammatory and antioxidant properties. Food Chemistry, 286, 8-16. PMid:30827670. http://dx.doi.org/10.1016/j.foodchem.2019.02.013

Lino, F. M. A., de Sá, L. Z., Torres, I. M. S., Rocha, M. L., Dinis, T. C. P., Ghedini, P. C., Somerset, V. S., \& Gil, E. S. (2014). Voltammetric and spectrometric determination of antioxidant capacity of selected wines. Electrochimica Acta, 128, 25-31. http://dx.doi.org/10.1016/j.electacta.2013.08.109

Lv, H.-P., Zhang, Y., Shi, J., \& Lin, Z. (2017). Phytochemical profiles and antioxidant activities of Chinese dark teas obtained by different processing technologies. Food Research International, 100(Pt 3), 486-493. PMid:28964372. http://dx.doi.org/10.1016/j.foodres.2016.10.024

Macêdo, I. Y. L., Garcia, L. F., Oliveira Neto, J. R., Siqueira Leite, K. C., Ferreira, V. S., Ghedini, P. C., \& Souza Gil, E. (2017). Electroanalytical tools for antioxidant evaluation of red fruits dry extracts. Food Chemistry, 217, 326-331. PMid:27664641. http://dx.doi.org/10.1016/j.foodchem.2016.08.082

McAlpine, M., \& Ward, W. (2016). Influence of steep time on polyphenol content and antioxidant capacity of black, green, rooibos, and herbal teas. Beverages, 2(3), 17. http://dx.doi.org/10.3390/beverages2030017

Mole, S., \& Waterman, P. G. (1987). A critical analysis of techniques for measuring tannins in ecological studies : I. Techniques for chemically defining tannins. Oecologia, 72(1), 137-147. PMid:28312910. http://dx.doi.org/10.1007/BF00385058

Moreno, E. K. G., Thomaz, D. V., Machado, F. B., Leite, K. C. S., Rodrigues, E. S. B., Fernandes, M. A., Carvalho, M. F., Oliveira, M. T., Caetano, M. P., Peixoto, C. E. C., Isecke, B. G., Gil, E. S., \& Macêdo, I. Y. L. (2019). Antioxidant study and electroanalytical investigation of selected herbal samples used in folk medicine. International Journal of Electrochemical Science, 14(1), 838-847. http://dx.doi.org/10.20964/2019.01.82

Oliveira Neto, J. R., Macêdo, I. Y. L., Oliveira, N. R. L., \& Ferreira, R., \& Gil, E. S. (2017a). Antioxidant capacity and total phenol content in hop and malt commercial samples. Electroanalysis, 29(12), 2788-2792. http://dx.doi.org/10.1002/elan.201700492

Oliveira Neto, J. R., Oliveira, T. S., Ghedini, P. C., Vaz, B. G., \& Gil, E. S. (2017b). Antioxidant and vasodilatory activity of commercial beers. Journal of Functional Foods, 34, 130-138. http://dx.doi.org/10.1016/j.jf.2017.04.019

Oliveira Neto, J. R., Rezende, S. G., Lobón, G. S., Garcia, T. A., Macedo, I. Y. L., Garcia, L. F., Alves, V. F., Torres, I. M. S., Santiago, M. F., Schmidt, F., \& Gil, E. S. (2017c). Electroanalysis and laccase-based biosensor on the determination of phenolic content and antioxidant power of honey samples. Food Chemistry, 237, 1118-1123. PMid:28763958.

http://dx.doi.org/10.1016/j.foodchem.2017.06.010

Oliveira Neto, J. R., Rezende, S. G., Fátima Reis, C., Benjamin, S. R., Rocha, M. L., \& Gil, E. S. (2016). Electrochemical behavior and determination of major phenolic antioxidants in selected coffee samples. Food Chemistry, 190, 506-512. PMid:26213003. http://dx.doi.org/10.1016/j.foodchem.2015.05.104

Petkova, N., Ivanova, L., Filova, G., Ivanov, I., \& Denev, P. (2017). Antioxidants and carbohydrate content in infusions and microwave extracts from eight medicinal plants. Journal of Applied Pharmaceutical Science, 7(10), 55-61. http://dx.doi.org/10.7324/JAPS.2017.71008

Reipa, V., Atha, D. H., Coskun, S. H., Sims, C. M., \& Nelson, B. C. (2018). Controlled potential electro-oxidation of genomic DNA. PLoS One, 13(1), e0190907. PMid:29324786. http://dx.doi.org/10.1371/journal.pone.0190907

Ren, K., Han, B., Lv, L., Zhang, G., Lei, L., Bai, X., Xiao, P., \& Li, M. (2019). Non-camellia tea in China: traditional usage, phytochemistry, and pharmacology. Chinese Herbal Medicines, 11(2), 119-131. http://dx.doi.org/10.1016/j.chmed.2019.04.001

Rolim, A., Maciel, C. P. M., Kaneko, T. M., Consiglieri, V. O., Salgado-Santos, I. M. N., \& Velasco, M. V. R. (2005). Validation assay for total flavonoids, as rutin equivalents, from Trichilia catigua Adr. Juss (Meliaceae) and Ptychopetalum olacoides Bentham (Olacaceae) commercial extract. Journal of AOAC International, 88(4), 1015-1019. PMid:16152916. http://dx.doi.org/10.1093/jaoac/88.4.1015

Sandasi, M., Chen, W., Vermaak, I., \& Viljoen, A. (2018). Non-destructive quality assessment of herbal tea blends using hyperspectral imaging. Phytochemistry Letters, 24, 94-101. http://dx.doi.org/10.1016/j.phytol.2018.01.016

Sgorbini, B., Cagliero, C., Acquadro, S., Marengo, A., Cordero, C., Liberto, E., Bicchi, C., \& Rubiolo, P. (2019). Evaluation of volatile bioactive secondary metabolites transfer from medicinal and aromatic plants to herbal teas: comparison of different methods for the determination of transfer rate and human intake. Journal of Chromatography. A, 1594, 173-180.

PMid:30770143. http://dx.doi.org/10.1016/j.chroma.2019.02.012

Shannon, E., Jaiswal, A. K., \& Abu-Ghannam, N. (2018). Polyphenolic content and antioxidant capacity of white, green, black, and herbal teas: a kinetic study. Food Research, 2(1), 1-11. http://dx.doi.org/10.26656/fr.2017.2(1).117

Shao, Y., Hu, Z., Yu, Y., Mou, R., Zhu, Z., \& Beta, T. (2018). Phenolic acids, anthocyanins, proanthocyanidins, antioxidant activity, minerals and their correlations in non-pigmented, red, and black rice. Food Chemistry, 239, 733-741. PMid:28873629. http://dx.doi.org/10.1016/j.foodchem.2017.07.009

Silveira, T. F. F., Meinhart, A. D., de Souza, T. C. L., Cunha, E. C. E., Moraes, M. R., Teixeira Filho, J., \& Godoy, H. T. (2017). Optimization of the preparation conditions of yerba mate tea beverage to maximize chlorogenic acids extraction. Plant Foods for Human Nutrition (Dordrecht, Netherlands), 72(2), 219-223. PMid:28466135. http://dx.doi.org/10.1007/s11130-017-0613-6

Teppone, M. (2019). Medicine has always been "Modern" and "Scientific" from ancient times to the present day. Journal of Integrative Medicine, 17(4), 229-237. PMid:30967348. http://dx.doi.org/10.1016/j.joim.2019.03.008 
Thomaz, D. V., Leite, K. C. S., Moreno, E. K. G., Garcia, L. F., Alecrim, M. F., Macêdo, I. Y. L., Caetano, M. P., Carvalho, M. F., Machado, F. B., \& Gil, E. S. (2018a). Electrochemical study of commercial black tea samples. International Journal of Electrochemical Science, 13(6), 5433-5439. http://dx.doi.org/10.20964/2018.06.55

Thomaz, D. V., Peixoto, L. F., Oliveira, T. S., Fajemiroye, J. O., da Silva Neri, H. F., Xavier, C. H., Costa, E. A., Santos, F. C. A., Souza Gil, E., \& Ghedini, P. C. (2018b). Antioxidant and neuroprotective properties of Eugenia dysenterica leaves. Oxidative Medicine and Cellular Longevity, 2018, 3250908. PMid:30327710. http://dx.doi.org/10.1155/2018/3250908

Zhang, C., Suen, C. L.-C., Yang, C., \& Quek, S. Y. (2018). Antioxidant capacity and major polyphenol composition of teas as affected by geographical location, plantation elevation and leaf grade. Food Chemistry, 244, 109-119. PMid:29120758.

http://dx.doi.org/10.1016/j.foodchem.2017.09.126

Funding: Coordenação de Aperfeiçoamento de Pessoal de Nível Superior - Brazil (CAPES) - Finance Code 001. 


\section{Supplementary Material}

Supplementary material accompanies this paper.

Table S1: Classification, coding, source and composition information for the various teas and tisanes purchased from Brazilian market

Table S2: Summary of results of the Response Surface Methodology analysis in the evaluation of the effects of phytochemicals contents in the antioxidant capacity of various teas and tisanes purchased from Brazilian market

This material is available as part of the online article from http://www.scielo.br/bjft 